CIVIL ENGINEERING CONTRACT ADMINISTRATION AND CONTROL 
By the same author

Civil Engineering Quantities, Third Edition

Civil Engineering Specification, Second Edition

Building Quantities Explained, Third Edition

Advanced Building Measurement

Building Economics, Third Edition

Building Technology, Third Edition

Building Maintenance

Building Surveys, Reports and Dilapidations

Quantity Surveying Practice

Municipal Engineering Practice

Local Government Explained

Planned Expansion of Country Towns (George Godwin)

Outdoor Recreation and the Urban Environment 


\section{CIVIL ENGINEERING CONTRACT ADMINISTRATION AND CONTROL}

\section{IVOR H. SEELEY}

BSc, MA, PhD, CEng, FICE, FRICS, MCIOB

Emeritus Professor of Trent Polytechnic, Nottingham and Chartered Civil Engineer and Surveyor

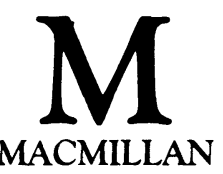


(C) Ivor H. Seeley 1986

Softcover reprint of the hardcover 1st edition 1986 978-0-333-40591-8

All rights reserved. No reproduction, copy or transmission of this publication may be made without written permission.

No paragraph of this publication may be reproduced, copied or transmitted save with written permission or in accordance with the provisions of the Copyright Act 1956 (as amended).

Any person who does any unauthorised act in relation to this publication may be liable to criminal prosecution and civil claims for damages.

First published 1986.

Published by

MACMILLAN EDUCATION LTD

Houndmills, Basingstoke, Hampshire RG21 2XS

and London

Companies and representatives

throughout the world

British Library Cataloguing in Publication Data

Seeley, Ivor $\mathrm{H}$.

Civil engineering contract administration and

control.-(Macmillan building and surveying

series)

1. Civil engineering-Contracts and specifications

-Great Britain

I. Title

$642 \quad$ TA181.G7

ISBN 978-0-333-40592-5

ISBN 978-1-349-18463-7 (eBook)

DOI 10.1007/978-1-349-18463-7

\section{Series Standing Order}

If you would like to receive future titles in this series as they are published, you can make use of our standing order facility. To place a standing order please contact your bookseller or, in case of difficulty, write to us at the address below with your name and address and the name of the series. Please state with which title you wish to begin your standing order. (If you live outside the United Kingdom we may not have the rights for your area, in which case we will forward your order to the publisher concerned.)

Customer Services Department, Macmillan Distribution Ltd Houndmills, Basingstoke, Hampshire, RG21 2XS, England. 
'For which of you, intending to build a tower, sitteth not down first, and counteth the cost, whether he have sufficient to finish it?'

Luke 14.28 



\section{Contents}

$\begin{array}{ll}\text { Preface } & \text { ix }\end{array}$

Acknowledgements $\quad$ x

List of Tables

List of Figures xii

1 Contractual Arrangements 1

Scope of civil engineering works; the Institution of Civil Engineers; funding of projects; parties to a contract; civil engineering contracts; preliminary investigations; engineers' reports.

2 Contract Documentation

Form and purpose of contract documents: Conditions of Contract; drawings; specification; bill of quantities; instructions to tenderers; form of tender; form of agreement; form of bond; ICE Conditions of Contract: introduction; engineer's representative; general obligations; workmanship and materials; commencement time and delays; completion and maintenance; alterations, additions and omissions; property in materials and plant; measurement; nominated sub-contracts; certificates and payment; remedies and powers; settlement of disputes; tax matters; metrication; contract price fluctuations; overseas forms of contract.

3 Estimating and Tendering

Broad aims; tendering procedures; selection of tenderers; supply of instructions and other information to tenderers; action during the tender period; alternative tenders; selecting invitations to tender; distinction between estimates and tenders; preliminary estimating procedures; preparation of estimates; compiling tenders; appraisal of tenders; notification and acceptance of tenders.

4 Site Organisation

Site personnel, management and planning; site layout; planning and monitoring of activities; resource scheduling; costing and accounting arrangements; productivity; plant usage, maintenance and costing; safety aspects. 
5 Site Supervision

Setting out; method of supervision of work on site; implementation of the specification; materials requirements; workmanship requirements; testing arrangements.

\section{Communication}

Methods and importance of communication; communications between parties to the contract; communications between site personnel; site documents and records; purpose and conduct of meetings.

7 Measurement and Valuation of Work

Measurement code and its application; measurement of work as executed; measurement and cost records; daywork; interim certificates and payments; final accounts; valuation of variations; financial control of contracts.

\section{Settlement of Contractors' Claims}

General background to claims; types of claims; procedural aspects; application of contract conditions; origination of claims; preparation of claims; action on submission of claims; additional cost for loss or expense; disruption of the works resulting from variations; liquidated damages. 


\section{Preface}

This book is aimed at civil engineers and civil engineering contractors and at students on civil engineering degree and diploma courses. Allied professions such as construction and quantity surveyors may find its contents of interest and value.

The diverse aspects of civil engineering contract administration are examined and described, with relevant supporting examples. It starts by considering the general backcloth to civil engineering works and contracts, including funding, preliminary investigations and the preparation of engineer's reports. The form and purpose of the various contract documents are examined and the principal requirements of the ICE Conditions summarised and explained.

The principal tendering arrangements are described and compared, together with the more commonly practised approaches to estimating the cost of civil engineering works.

Site organisation and supervision are covered in sufficient depth to illustrate the means by which a civil engineering project can be effectively planned, managed and controlled, and having regard to such important aspects as productivity, plant usage and safety of operatives.

One of the major problems encountered in the operation of civil engineering contracts is a weakness in communication between the parties to the contract and site personnel. Vital communication requirements are described and illustrated, including the preparation of site documents and records and the purpose and conduct of site meetings.

The method of measuring and valuing civil engineering works is explored and this encompasses the use of daywork, issue of interim certificates, settlement of final accounts, valuation of variations and financial control of contracts.

Finally, the book examines the background to contractors' claims and how they should be presented by the contractor and dealt with by the engineer. The disruptive effect of variations and the main causes of loss and expense to the contractor are considered at length, together with the assessment of liquidated damages.

Nottingham

IVOR H. SEELEY

Spring 1986 


\section{Acknowledgements}

A debt of gratitude is owed to many civil engineers who have over the years given me the benefit of their knowledge and experience.

My thanks are due to the Institution of Civil Engineers for kind permission to quote from the Conditions of Contract for use in connection with Works of Civil Engineering Construction and to reproduce figure 4.1 from Civil Engineering Procedure published by Thomas Telford Ltd. Permission was also given to reproduce figure 4.2 from The Practice of Construction Management by Barry Fryer, 1985, Collins Professional and Technical Books.

Macmillan Publishers kindly gave permission to quote from Civil Engineering Quantities, Civil Engineering Specification and Quantity Surveying Practice.

I received abundant help and consideration from the publishers throughout the preparation and production stages of the book. Mrs. E.D. Robinson prepared the typescript quickly and efficiently and my wife played her customary supportive role. 


\section{List of Tables}

2.1 Specification of tunnel and shaft linings

3.1 Rental charge for a crawler hydraulic shovel loader

3.2 Cost of one-brick wall in engineering bricks (class B) in cement $\operatorname{mortar}(1: 3) / \mathrm{m}^{2}$

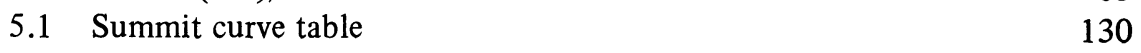

5.2 Slump and compacting factor test limits 153

6.1 Samples for examination form 184

6.2 Form of application for employment 186

6.3 Statement of particulars of engagement 187

6.4 Extracts of an agenda of a project meeting 190

7.1 Sewer schedule 200

$\begin{array}{ll}7.2 & \text { Daywork schedule } \\ 7.3 & \text { Prowsionas }\end{array}$

7.3 Provisional sums for daywork 203

$\begin{array}{ll}7.4 \text { Daywork account } & 207\end{array}$

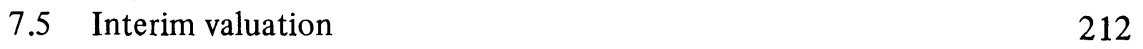

8.1 Under-recovery claim 251 


\section{List of Figures}

1.1 Records of boreholes on sewage treatment plant site 24

4.1 Chart of a contractor's typical site organisation 93

4.2 Typical personnel department structure 96

4.3 Critical path network 105

4.4 Programme and progress chart 107

5.1 Timber square 125

$\begin{array}{lll}5.2 & 3: 4: 5 \text { rule } & 126\end{array}$

5.3 Profiles 126

5.4 Setting out a curve 128

5.5 Diagram of summit curve 129

5.6 Sight rails 131

5.7 Chart of engineer's site team organisation $\quad 134$

6.1 Extracts from a site diary 182 